\title{
Current Status of Pediatric Formulations for Chronic and Acute Children' Diseases: Applications and Future Perspectives
}

\author{
Kronik ve Akut Çocuk Hastalıkları için Pediatrik Formülasyonların Mevcut \\ Durumu: Uygulamalar ve Gelecekteki Bakış Açıları
}

\section{Panoraia SIAFAKA $\odot$, Esra IPEKCI $\odot$, Emre Sefik CAGLAR $\odot$, Neslihan USTUNDAG OKUR $\odot$, Derya BUYUKKAYHAN $\odot$}

Ethics Committee Approval: Not applicable.

Conflict of interest: The authors declare that they have no conflict of interest.

Funding: None.

Informed Consent: Not applicable.
Cite as: Siafaka P, Ipekci E, Caglar ES, Ustundag Okur N, Buyukkayhan D. Current status of pediatric formulations for chronic and acute children' diseases: applications and future perspectives. Medeni Med J. 2020;35:152-62.

\begin{abstract}
Infants and other children can be affected by various acute, chronic and many of them rare illnesses. Developing drugs for children is very challenging since they cannot intake tablets or hard oral solid dosage forms. Besides, most of the prescribed pediatric medications are unlicensed. The biggest issue that clinicians have to solve is that dosing in children is not based on weight or surface area of the body, as it happened in adults but is related to age variations in drug absorption, distribution, metabolism, and elimination. Thus, for pediatric patients, various therapeutic approaches have been proposed so as to develop suitable formulations such as liquid dosage forms, flexible capsules, milk-based products, etc. In addition, the administration of current pharmaceutical products to children might lead to some serious side effects which can also happen in adults but with a lower risk. Especially, infants are at high risk of getting poisoned by taking drugs used for adults. Moreover, children are very sensitive to the taste and smell of some pharmaceutical vehicles and can resist to intake them and this situation leads parents to search for tasteless and odorless medications. In this study, the current formulations for various diseases intended to be used in pediatric patients as well as various chronic and acute diseases of childhood are summarized. Authors believe that this review can help professionals who want to work with pediatric formulations to design more efficient and child-friendly drug delivery systems.
\end{abstract}

Keywords: Pediatric diseases, pediatric formulations, drug delivery systems, infants, children, pharmaceutical technology

öz

Çocuklar ve bebekler, çoğunun nadir olduğu çeşitli akut ve kronik hastalıklardan etkilenebilirler. Cocuklar için ilaç geliștirmek, tabletleri veya sert oral katı dozaj formlarını alamadıkları için çok zordur. Bunun dışında çocuklar için reçete edilen ilaçların çoğu ruhsatsızdır. Klinisyenlerin çözmesi gereken en büyük sorun, çocuklarda dozlamanın yetişkinlerde olduğu gibi ağırlık veya yüzey alanına bağlı olmaması, ilaç emilimi, dağılımı, metabolizması ve eliminasyonundaki yaş varyasyonları ile ilgili olmasıdır. Bu nedenle, pediyatrik hastalar için sıvı dozajlar, esnek kapsüller, süt bazlı olan ürünler gibi uygun formülasyonlar geliştirmek için çeşitli terapötik yaklaşımlar önerilmiștir. Ayrıca, mevcut tıbbi ürünlerin çocuklara uygulanması, yetișkinlerde ortaya çıabilecek ancak daha yüksek risk taşıyan bazı yan etkilere neden olabilir. Özellikle bebeklerin yetişkinler için kullanılan ilaçları alarak zehirlenme riski yüksektir. Dahası, çocuklar bazı ilaç araçlarının tadına ve kokusuna karşı çok hassastırlar ve bu durum ebeveynleri tatsız ve kokusuz ilaçlar aramaya yöneltmektedir. Bu çalışmada, çocuk hastalarda kullanılması amaçlanan çeşitli kronik ve akut çocukluk hastalıkları için güncel formülasyonlar özetlenmiştir. Yazarlar, bu incelemenin, pediyatrik formülasyonlarla çalışmak isteyen profesyonellerin daha verimli ve çocuğa uygun ilaç taşıyıcı sistemlerin tasarlamalarına yardımcı olabileceğine inanıyor.

Anahtar kelimeler: Pediyatrik hastalıklar, pediyatrik formülasyonlar, ilaç taşıyıcı sistemler, bebekler, çocuklar, farmasötik teknoloji
Received: 28 February 2021

Accepted: 29 May 2021

Online First: 18 June 2020

Corresponding Author: D. Buyukkayhan

ORCID: 0000-0001-7172-0812

University of Health Sciences, Faculty of Medicine, Department of Pediatrics, Division of Neonatology, İstanbul, Turkey

derya.buyukkayhan@sbu.edu.tr

P. Siafaka

ORCID: 0000-0001-7256-3230

Aristotle University of Thessaloniki, Department of Chemistry, Thessaloniki, Greece

E. Ipekci

ORCID: 0000-0002-7299-8127 E. S. Caglar

ORCID: 0000-0003-2010-4918 N. Ustundag Okur ORCID: 0000-0002-3210-3747 University of Health Sciences, Faculty of Pharmacy, Department of Pharmaceutical Technology, İstanbul, Turkey 


\section{INTRODUCTION}

The development of safe and effective formulations for pediatric patients is a major challenge since they have different pathophysiologic and pharmacokinetic mechanisms compared to adults. Infants and other children might absorb, distribute, eliminate, and discrete drugs in different ways compared to adults ${ }^{1}$. Therefore, current medications prescribed for adults cannot be used for young people. Drug absorption in childhood is highly affected by changes in accordance with the gastric $\mathrm{pH}$ and stomach emptying time ${ }^{2}$. Especially, the gastric $\mathrm{pH}$ is neutral at birth and decreases in two to three days after birth. This process continues for weeks or years until being reached to the gastric $\mathrm{pH}$ of an adult stomach ${ }^{3}$. It was reported that gastric emptying time is slower at six to eight monthold infants as a result of the immaturity of the neuroregulation of gastric motility ${ }^{4}$. In addition, a child's body contains higher amount of water and therefore lower plasma protein concentration when compared to an adult. This situation causes different drug distribution rates in the organs of a child. Another important factor to be considered is the possibility of the presence of metabolic disorders in infants that may result in reduced drug excretion and prolonged drug half-life. Especially in infants, renal clearance decreases as a result of immature glomerular filtration, tubular secretion, and tubular reabsorption ${ }^{2,5}$. As a result, it is very important to effectively determine the safe and adequate doses of drugs intended for prescribing to children, newborns, and infants. Thus, it is highly necessary to understand the pharmacokinetics and pharmacodynamics of drugs to achieve adequate concentration when used in children ${ }^{1}$. Clinicians should evaluate the above parameters and the unique clinical signs of each pediatric patient to administer the best and adequate dosage. There are various routes of drug administration for children such as oral ${ }^{6}$, dermal-transdermal ${ }^{7}$, rectal, intramuscular, and inhalation $^{8}$.
The oral route is the most preferred route of administration of the drug formulations in case of chronic diseases, because it is easy to administer compared to other drug formulations, whereas the intravenous route is an important route of administration for acute disorders. However, when using oral dosage forms the main problem is how children will swallow or accept taking the medicine without complaint. In addition, the ability to swallow in children can be obtained around the age of six. Therefore, it is recommended to use liquid formulations at earlier ages, as the unpleasant odor or taste of the drug can be masked by various sweeteners and flavors ${ }^{9}$. Nonetheless, still many oral medications are available as tablets or larger forms and these medications are difficult to swallow and also cause unpleasant child behavior. For this reason, doctors and parents can contemplate different routes of administration, such as crushing, breaking, or mixing the drug into meals, which may lead to a decrease in the therapeutic efficacy of the drug $^{10,11}$. In order to overcome this problem, granules or orodispersible tablets can be used, but the taste of the excipients in these formulations should be within acceptable limits for pediatric patients. Another route of administration with various advantages is transdermal application. As the largest organ of the human body, the skin is an alternative route in pediatric drug applications due to its high surface area. According to the transdermal route, the drugs can reach systemic circulation by passing through the dermal layers. However, the skin acts as a barrier limiting dehydration and drug entry, especially in infants and older children. On the other hand, such a barrier function may be advantageous in order to achieve adequate therapeutic concentrations without risks of toxicity ${ }^{7}$. Today, although not for all drugs, various transdermal patches containing active drug ingredients such as fentanyl, clonidine, scopolamine are applied to pediatric patients ${ }^{7}$. Inhalation products are mostly used for the treatment of asthma and Chronic Obstructive Pulmonary Disease (COPD) in pediatric patients. 
Intramuscular route is another important route for the delivery of a pediatric drug. This route has some disadvantages in terms of pharmacokinetic parameters such as the time to achieve the desired drug concentration. It is especially not reliable in infants. On the other hand, drug molecules like aminoglycosides and ampicillin show similar pharmacokinetic behaviors in infants, children, and adults; like the time which is needed to reach the maximum plasma concentration ${ }^{12}$. Rectal administration is preferred for patients who cannot use oral dosage forms because the rectum is well vascularized leading to the desired adsorption ${ }^{12}$. Figure 1 summarizes the most frequently used pediatric formulations and their routes of administration. Ocular and nasal formulations can of course be administered to pediatric patients with caution and according to their toxicity profiles.

Although new pediatric formulations are desperately needed, it can be said that researchers do not focus on their development. This fact can be related to the cost-effectiveness of pediatric products. Also, many medicines offer flavors unacceptable to children, and masking the bitterness or strange taste or smell of medicines with sweeteners or other means can require application of expensive methods. However, pediatricians, caregivers, and parents will be happy with the development of drug formulations specifically designed for children. This review aims to assist the pharmaceutical technologists or other scientists by summarizing the current

\section{Most frequent used pediatric formulations and preferable administration routes}

\section{Oral dosages}

uSolid (tablets, pills)

口Liquid (syrup, suspensions)

口Chewable tablets

Transdermal patches

口Microneedles

Dlontophoretic

aDrug in adhesive

\section{Rectal formulations}

口Creams-ointments

口Suppositories

DFoams

口Sprays

DEnemas

\section{Intravenous-Intramuscular formulations}

Ulnjections
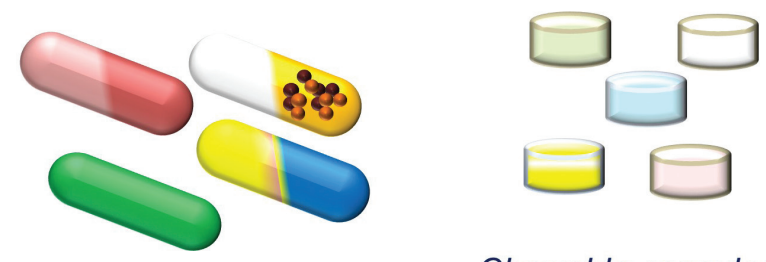

Chewable capsules

Tablets, capsules

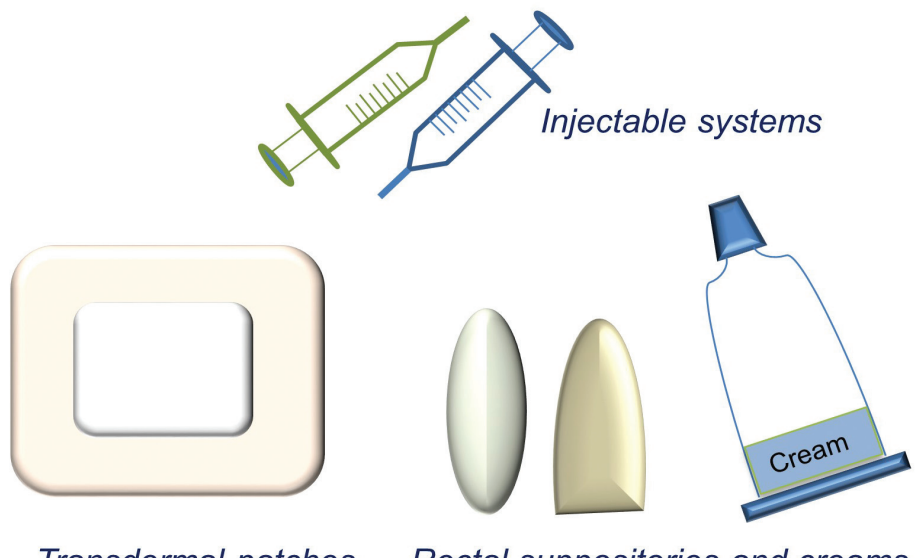

Transdermal patches

Rectal suppositories and creams

Figure 1. A summary of the current pediatric formulations and their administration routes. 


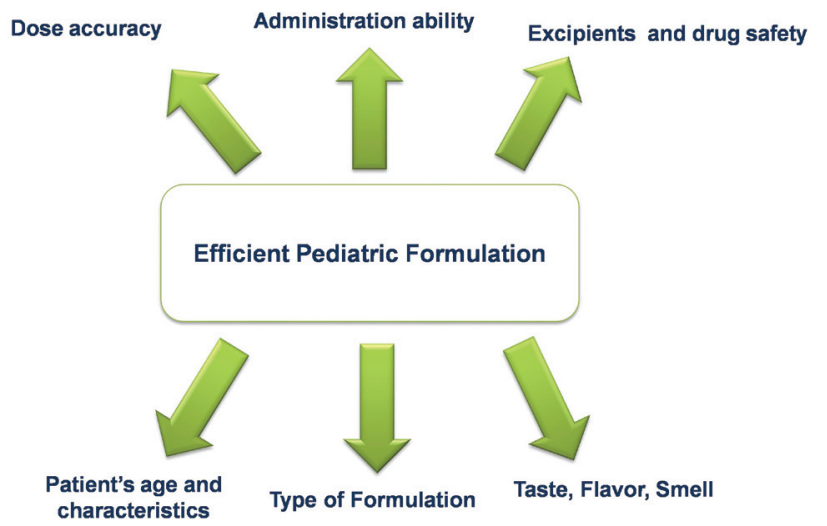

Figure 2. Various factors which should be considered to develop a pediatric formulation.

formulations used for pediatric patients and their diseases in target.

\section{Chronic and Acute diseases of childhood}

Childhood is called to the age from birth till puberty, including adolescence. Because children can easily socialize, and vulnerable to various diseases due to environmental factors. Table 1 summarizes the most common diseases of children. Obesity is the main risk for children, especially today. A major concern is that children who are suffering from obesity which has been associated with increased mortality, risk of metabolic and cardiovascular syndromes, cancer, and so on are multiplying day by day ${ }^{13}$. The second frequently seen disease that should be taken into consideration is diabetes mellitus (DM). DM is a syndrome commonly found in children and adolescents where insulin secretion is relatively decreased or peripheral resistance to the action of insulin is impaired ${ }^{14}$. Type I DM occurs in the pancreatic islets where insulin-producing beta cells are destroyed by autoimmunity, resulting in abnormal glucose tolerance and eventually ketoacidosis whereas Type II DM is characterized by hyperglycemia and insulin resistance as well as relative impairment in insulin secretion ${ }^{14}$.

Viral infections are quite common during childhood and adolescence. At present, some viral infections can be prevented by vaccination while others can be treated by managing the symptoms. Viral diseases that can be prevented by vaccination are: a) measles caused by the rubeola virus, b) rotavirus (RV) infection which is a common cause of childhood gastroenteritis, c) varicella-zoster virus which commonly causes varicella (chickenpox), mumps, and d) hepatitis A and B virus infections. The viruses that are causing pediatric infections that can be treated by using medications include

Table 1. The most common diseases, their symptoms, and possible treatments.

\begin{tabular}{|c|c|c|}
\hline Name & Symptoms & Treatments \\
\hline Common cold & $\begin{array}{l}\text { Runny nose, congestion, sneezing, sore throat, } \\
\text { coughing }\end{array}$ & Fluids, rest, and time \\
\hline Roseola & Irritability, sore throat, fever, small red spots & Acetaminophen or ibuprofen and time \\
\hline Parvovirus B19- fifth disease & Lacy red rash, low-grade fever. = & Pain relievers if the rash is painful \\
\hline Gastroenteritis & Vomiting, diarrhea or loose stools, fever & Time, fluids \\
\hline Strep throat & $\begin{array}{l}\text { High temperature, sore throat, red tonsils/throat, } \\
\text { swollen covered by white patches, inflamed taste } \\
\text { buds, appetite loss, nausea, rash, muscle /joint } \\
\text { aches }\end{array}$ & Antibiotics \\
\hline Flu (influenza) & $\begin{array}{l}\text { High fever, great fatigue, sore throat, cough, hea- } \\
\text { dache and body aches, nausea, vomiting, diarrhea }\end{array}$ & Ibuprofen or acetaminophen, time,rest \\
\hline Viral, bacterial, allergic conjunctivitis & Pink/red eye & Ocular drops \\
\hline Hand-Foot-Mouth Disease & $\begin{array}{l}\text { Low fever, headache, sore throat, sores in the } \\
\text { mouth, palate and/or tonsils, appetite loss, spotty } \\
\text { rash, blisters on hands, feet and/or bum }\end{array}$ & Acetaminophen \\
\hline
\end{tabular}


the cytomegalovirus, herpes simplex virus, and influenza. In addition, respiratory syncytial virus (RSV) is associated with bronchiolitis and often causes hospitalization in the first year of life. Human rhinovirus is the common source of the cold while noroviruses are associated with cases of gastroenteritis. Epstein-Barr Virus is the most common etiologic agent of acute parvovirus B19 infection, whereas enteroviruses are the causative agents of up to $90 \%$ of diagnosed cases of viral meningitis ${ }^{15}$.

Otitis is one of the common infections in children. Acute otitis media is an infection of the middle ear fluid that causes acute, suppurative disease and inflammation of the mucosa covering the middle ear space. The most commonly isolated pathogens in children suffering from acute otitis media are Streptococcus pneumoniae, Haemophilus influenza, and Moraxella catarrhalis ${ }^{16}$. Acute otitis externaisageneralized inflammation of theexternal auditory canal and leads to duct skin cellulitis. The pathogens detected in cases with acute otitis externa are mostly Pseudomonas aeruginosa and Staphylococcus aureus ${ }^{17}$. Tonsillopharyngitis is also very common in pediatric populations. The most common pathogen isolated in this infection is Streptococcus pyogenes which must be treated using antibiotics ${ }^{18}$. Acute bacterial sinusitis is a bacterial infection of the paranasal sinuses that occurs due to a viral infection of the upper respiratory tract ${ }^{17}$. Pneumonia and pneumonitis are inflammatory conditions of the lungs and they can be caused by viruses, bacteria, or fungi ${ }^{19}$. Asthma is a chronic syndrome that causes inflammation in the middle and small airways, increased bronchial smooth muscle constriction and hypersensitivity, edema and mucosal degradation, as well as obstruction of the airway lumen by mucus ${ }^{20}$. Children are also suffering from eye infections. One of these infections is conjunctivitis. Staphylococcus aureus, Streptococcus pneumoniae, Haemophilus influenzae, and Moraxella catarrhalis are the main pathogens of the eye infections such as bacterial conjunctivitis $^{21}$. Various skin conditions such as atopic dermatitis, pityriasis alba, tinea versicolor, and so on could occur in pediatric populations as well ${ }^{22}$. The skin disorders described above may affect the self-esteem of the child ${ }^{23}$. Atopic dermatitis and eczema are the most common types of skin disorders ${ }^{24}$.

In general, there are numerous disorders that children can be affected by. Diseases or sensitivities such as autoimmune diseases, disorders with unknown etiology, food allergies, celiac disease, gluten allergy, and lactose intolerance can be seen during childhood. The most important point for parents is to be alerted and to identify possible health problems of their children and communicate their concerns with their pediatricians.

\section{Pharmaceutical products for pediatric delivery}

As it was reported above, limited pharmaceutical products have been approved as pediatric formulations. It is quite important to recognize that most of the formulations used by children are not licensed by any authority, but the dosage limit is set by crushing tablets when solid oral products are used, or by other methods for liquid formulations. Children may complain about the taste or smell of the dosage form and could refuse to take the drug because of these reasons. In this regard, infants are most frequently treated by using syrups while neonates with suppositories. Children in their second to the fifth year of their life, use oral solutions, syrups, and suspensions. Older children (6-11 years) are treated with disintegrating or chewable tablets and thin strips while adolescents mainly use oral tablets, capsules, powders, etc ${ }^{25}$. Liquid forms are the most popular since they can be easily administered by the caregiver ${ }^{26}$. In the following section, the most important, and indispensable characteristics of the ingredients of the pediatric formulations are discussed.

\section{Characteristics and properties of pediatric formulations}

In general, pediatric formulations need to have several baseline properties to be approved 
and accepted by children (Figure 2). More specifically, pharmaceutical products should offer efficient and predictable bioavailability. In addition, both active molecules and excipients should demonstrate toxicologically safe profile and uniform drug dosage. Furthermore, they should present desirable properties such as palatability, handling, easy administration, safe packaging, and accurate information for use ${ }^{27}$. According to the European Medical Agency (EMA), several considerations must be taken into account to design an effective medicinal product for pediatric use. Some of these considerations are the target age group, critical dose regimen, maximum duration of treatment, and dosing frequency as well as characteristics and behavior of the child and the caregiver ${ }^{28}$. In addition, given the low solubility of most drugs and the use of salt forms, it should be considered that the form intended for use in children will be different from that used for adults. In addition, EMA guidelines suggest that the development of fixed-dose combinations can be developed as alternative therapeutic approaches for pediatric patients with chronic (HIV or tuberculosis) disease who are currently being treated with single agents. The recommended dosing frequency should be adjusted according to the active molecule, the pharmacokinetics as well as the indication, the convenience, and therapeutic compliance of the child or the caregiver ${ }^{28}$. Thus, the use of prolonged-release formulations as transdermal patches might be a solution for reducing dosing frequency. Preservatives should be used carefully since limited data are available for their possible toxicity to children ${ }^{28}$.

One of the most challenging aspects when designing pediatric formulations is which excipients are best suited. The excipients have to be carefully selected as they must be nontoxic, patient-friendly, and functional. Coloring agents, flavors, preservatives, and sweeteners must be used with caution and justified for any possible allergic reactions they may trigger. It has already been reported that active molecules or other compounds added to pharmaceutical formulations may have a bitter taste. This is the reason why the addition of sweeteners (xylitol, sorbitol, and others) is widely used in the preparation of pharmaceutical products. The use of sweeteners is not always desirable as it will lead to the development of caries and other dental problems, given that children with chronic diseases may be exposed to higher levels of sugar load $^{25}$. Also, obese and diabetic patients should consume a limited amount of sugar; therefore, adding sweeteners will be detrimental to them. Another method of masking the bitter taste of the ingredients in the formulation is to use sodium salts because the salt taste is preferred by children compared to adults. Among others, the use of phosphatidic acid- $\beta$-lactoglobulin, glutamate, adenosine monophosphate are also being used to mask the bitter taste ${ }^{29}$. Flavoring agents should be selected effectively since children are quite strict with their flavors. Coloring agents accepted for pediatric formulations are quite limited; i.e. while based on recommendations use of azodyes in pediatric medicines is forbidden, natural coloring agents have been associated with allergic reactions ${ }^{30}$. Another issue that should be considered is the usage of lactose as a binder and filler. Lactose can intrigue hypersensitivity or allergic reactions to infants and other children ${ }^{31}$. Finally, the use of solubility enhancers such as ethanol and glycerol should be limited, because large amounts of ethanol are associated with undesirable symptoms in the central nervous system $^{30}$.

\section{Recently approved pediatric formulations}

Currently, limited number of formulations are specifically licensed for administration to infants, other children, and adolescents. Some of them are recommended for use in patients of a certain age. Table 2 summarizes the recently approved FDA products for pediatric medical use. 
Table 2. Some of the recently FDA-approved pediatric medicaments

\begin{tabular}{|c|c|c|c|}
\hline Name of drug & Disease & Formulation & Year \\
\hline Ixekizumab & Plaque psoriasis(moderate-severe) & Injectable & 2020 \\
\hline Crisaborole & Atopic dermatitis (mild moderate) ( 3 months $\leq 2$ years old) & Ointment & 2020 \\
\hline Sofosbuvir/velpatasvir & Chronic hepatitis $C$ virus (genotypes $1,2,3,4,5$, or 6 ) ( $\geq 6$ years old) & Oral tablets & 2020 \\
\hline Vilazodone hydrochloride & Depression & Oral tablets & 2020 \\
\hline Fidaxomicin & Clostridium difficile- diarrhea ( $\geq 6$ months- 17 years old) & Oral tablets & 2019 \\
\hline Micafungin & Candidemia, acute disseminated candidiasis ( $\leq 4$ months) & Injectable & 2019 \\
\hline Levamlodipine & Hypertension ( $\geq 6$ years old) & Oral tablets & 2019 \\
\hline Insulin aspart & Diabetes mellitus & Injectable & 2019 \\
\hline Tazarotene & Acne & Topical & 2019 \\
\hline Paclitaxel & Recurrent or refractory pediatric solid tumors & Injectable & 2019 \\
\hline Calcipotriene & Scalp and body plaque psoriasis ( $\geq 4$ years old) & Topical & 2019 \\
\hline Minocycline & Acne vulgaris lesions (moderate-severe) ( $\geq 9$ years old) & Topical & 2019 \\
\hline Ravulizumab-cwvz & $\begin{array}{l}\text { Atypical hemolytic uremic syndrome to inhibit complement-mediated } \\
\text { thrombotic microangiopathy ( } \geq 1 \text { month old) }\end{array}$ & Injectable & 2019 \\
\hline Cobicistat & Along with darunavir for HIV-1 (Mass $\geq 35 \mathrm{~kg}$ ) & Oral tablets & 2019 \\
\hline Abobotulinumtoxin A & Upper limb spasticity ( $\geq 2$ years old) & Injectable & 2019 \\
\hline Ceftaroline fosamil & Acute Bacterial Skin and Skin Structure Infections (birth $-\leq 2$ months) & Injectable & 2019 \\
\hline Mixed salts of a single-entity amphetamine & Attention Deficit Hyperactivity Disorder & Capsules & 2019 \\
\hline Glucagon & Severe hypoglycemia ( $\geq 2$ years of age and older) & Injectable & 2019 \\
\hline Pregabalin & Treatment of partial-onset seizures & Oral solution & 2019 \\
\hline Pitavastatin & $\begin{array}{l}\text { Heterozygous familial hypercholesterolemia for decrement of elevated } \\
\text { Total Cholesterol, Low Density Lipoprotein-C, and Apolipoprotein B ( } \geq 8 \\
\text { years of age and older) }\end{array}$ & Oral tablets & 2019 \\
\hline Belimumab & Systemic lupus erythematosus (SLE) (5-17 years of age and older) & Injectable & 2019 \\
\hline Ceftazidime/ avibactam & $\begin{array}{l}\text { Complicated urinary tract infections and intra-abdominal infections } \\
\text { ( } 3 \text { months to } \leq 18 \text { years) }\end{array}$ & Injectable & 2019 \\
\hline
\end{tabular}

\section{Pharmaceutical pediatric formulations under development}

Today, the drugs for pediatric patients are dosage forms delivered through various administration routes, mostly used for adults. The main routes of administration are oral, parenteral, transdermal, nasal, rectal, and ocular; however, limited data are available for acceptability and safety of such pediatric formulations. The most important factor to be considered is whether the excipients used for the preparation of the formulations are safe during the developmental course. Moreover, limited research examining pediatric formulations and preparation methods are available in the literature. The most recent studies are presented as follows.

\section{Oral formulations}

Oral administration of drugs is among the most preferred routes for both adults and children. Oral routes of drug delivery can be used for a variety of acute or chronic illnesses. The development 
of pediatric oral formulations is very difficult, especially in terms of producing a dosage form in which the administration dose can be based on body weight ${ }^{32}$. The available oral formulations include solutions, syrups, suspensions, powders, capsules, granules, tablets, orally disintegrating tablets, chewable or dispersible tablets, oral thin strips, chewing gums, suspensions, oral drops, etc ${ }^{33}$. Minitablets are dosage forms that show the flexibility of dosing as well as the easy administration of the drugs to the the pediatric population ${ }^{34}$. It was shown that tablets smaller than two $\mathrm{mm}$ can be administrated to infants older than six months. In addition, vigorously dissolving small tablets of two $\mathrm{mm}$ size can be administered in the early period ${ }^{35,36}$. The most commonly used oral formulations are syrups and suspensions. However, while pediatric patients may complain of unpleasant taste or odor, manufacturing processes can be affected by the solubility and stability of these dosage forms ${ }^{37}$. Most importantly, liquid formulations are desirable for neonates, infants, and young children, taking care to avoid the risk of choking ${ }^{34}$. In addition, chewable formulations such as chewable tablets, soft chews, and chewing gums are developed to assist the disintegration and/or dissolution of the active molecules in the mouth ${ }^{8}$.

Recently, Silva Goes et al. have produced an oral liquid formulation for the administration of captopril to pediatric patients. Captopril is recommended for children with heart failure; thus, the research group designed a stable captopril liquid dosage form using EDTA, citric acid, dihydrate sodium citrate, and sucralose as excipients. Sucralose played the role of the sweetener. According to stability studies, it was revealed that the most influencing factor on the stability of formulations is their $\mathrm{pH}$. Moreover, the type of water and EDTA concentration also affected the stability. Mineral water improved the stability of captopril. Subsequently, the stable liquid formulation was produced using $0.08 \%$ EDTA at $\mathrm{pH} 3.8538$. Cinnarizine is used for vertigo and travel sickness.
Aman et al. ${ }^{39}$ prepared cinnarizine-loaded microspheres as oral formulations. Microspheres prepared by ionic gelation showed enhanced stability, organoleptic properties, and easy administration. The natural polymer, chitosan was cross-linked with tripolyphosphate anion and the developed microspheres showed improved physicochemical properties. Besides, the oral bioavailability study of the microspheres for rats showed an improved degree of bioavailability with a long mean residence time when nanocarriers (190 nm) were loaded with almost $74.3 \%$ of the drug. Clarithromycin is an antibiotic widely used for the treatment of various infections. Akre et al. ${ }^{40}$ prepared microspheres with clarithromycin, as a pediatric dry suspension. As a microencapsulation method, the simple solvent evaporation process was applied. They chose Eudragit L100 as a taste masking agent. According to the results, the suspension showed acceptable parameter limits such as sedimentation volume, flocculation degree, drug content, and $\mathrm{pH}$. In addition, a better release profile and taste compared to the marketed preparation were depicted. Padmavathi et al. ${ }^{41}$ produced dispersible tablets to be administered as a fixed-dose combination in pediatric HIV patients (one to eight years of age). The developed tablets combined with stavudine, lamivudine, and nevirapine were used for the administration of the correct weight-related doses. The formulations were produced by a direct compression method using various concentrations of super disintegrants such as croscarmellose sodium, sodium starch glycolate, as well as crospovidone. It was revealed that the tablet developed with croscarmellose sodium exhibited great in vitro dispersion time and drug release. Recently, Omar et al. ${ }^{42}$ prepared griseofulvin loaded b-cyclodextrinbased nanosponges as pediatric formulations. The dosage forms showed improved bitter taste masking properties, dissolution rate, and oral bioavailability. The authors also performed in vivo pharmacokinetic studies on rats revealing that the nanosponges provided great improvement in dissolution efficiency, as well as increment in 
Cmax and AUCO-48 compared to a plain drug. Granisetron is a 5HT3 receptor antagonist used to prevent nausea and vomiting before radiotherapy and chemotherapy. Kadhim et al. ${ }^{37}$ developed granisetron-loaded novel pediatric oral jelly formulations. The authors aimed to improve patient compliance and to achieve maximum therapeutic efficacy. While heat and congealing methods were chosen in the preparation of jelly products, gelatin and carrageenan were used as natural gelling agents. As an ideal candidate, the jelly formulation with $4.5 \%$ gelatin was selected since it showed the highest drug release rate of $99.4 \%$ in $15 \mathrm{~min}$. and the most favorable physicochemical parameters. An oral powder for the pediatric delivery of theophylline was developed and characterized by Nese et al. ${ }^{43}$ Milk-based powders developed by spray drying can be applied for oral administration of various molecules as they have showed good stability.

\section{Other administration routes of formulations}

Although oral administration seems to be the most preferred and easy route of administration, other alternative routes can also be used. The rectal route is suitable for its either local (eg management of constipation, hemorrhoids, pain) or systemic (eg, management of pain, infection, and central nervous system diseases) effects. In addition, it skips hepatic first-pass metabolism considering that the active molecules could be absorbed through systemic circulation ${ }^{44}$. According to a study, anal fissure treatment in children can be benefited by the topical administration of poly(ethylene glycol) and diltiazem ${ }^{45}$.

Intranasal administration of pediatric formulations is another preferred route, as it will act rapidly, similar to intravenous therapy ${ }^{8}$. Bhuva et al. ${ }^{46}$ developed a xylometazoline nasal spray formulation for children. The optimized nasal product comprised $0.105 \mathrm{~g}$ sodium cholate and $1.35 \mathrm{ml}$ poly(ethylene glycol) 400. The stable formulations offered improved in vitro release properties compared to the marketed product and could therefore alternatively be used for nasal congestion. Several ocular forms, as drops, ointments, gels, and inserts are frequently used in pediatric patients especially in the treatment of common eye infections, inflammation allergy, uveitis and glaucoma, and conditions such as myopia, amblyopia, and strabismus ${ }^{8}$. Dreno et al. ${ }^{47}$ developed eye drops containing $0.2 \%$ phenylephrine hydrochloride as an active ingredient, disodium hydrogen phosphate as a buffering agent in sterile water for injection, and sodium chloride as an isotonic agent in order to use in the retinal examination of newborns and premature infants. The results of the study showed that the developed ocular solutions were stable for at least 60 days.

Since the drug can be released sustainably from transdermal products for days, they can also be useful for the management of chronic diseases. For example, the methylphenidate transdermal system was applied for the management of Attention-Deficit Hyperactivity Disorder in one study. The drug-loaded adhesive patch showed advantageous properties as the dose was administered once a day and flexible usage times were reported $^{48}$. In another study, $2 \%$ ozenoxacinloaded cream formulation was applied topically to 644 pediatric patients with impetigo to investigate the effectiveness of the cream. The result of the study stated that the cream applied was an effective and safe treatment for impetigo in patients between two months and 18 years old ${ }^{49}$. Karlsson et al. ${ }^{50}$ studied porcine xenograft or a silver-foam dressing for the treatment of children with partial-thickness scalds. Fifty-eight children were included in the study. It was demonstrated that wound healing was faster, less changes were made in wound dressing, and also dressing times were also shorter.

\section{CONCLUSIONS}

This article focuses on the current aspects of the design and development of pediatric drug 
formulations. Pediatric patients (neonates, infants, children, and adolescents) cannot use the same formulations as adults because of their different body functions. The drug dosing differs greatly even between adults and children who have the same illness. Also, the drug adsorption and excretion, leading to undesirable side effects, is significantly different from that of an adult. At the same time, children are not as tolerant of the smell or taste of the drugs as adults. Children would refuse to get drugs with a bitter taste or irritating smell. Hence, novel and promising therapeutic formulations targeting pediatric diseases should be designed and developed. Recently, new pediatric formulations were approved by the FDA for various diseases. Despite this, the development of pediatric formulations is still at an early stage. It was only in recent years that more and more products got a license to be used for children. In most cases, clinicians recommended adult medications and adjusted the dose with various methods. In addition, when the pediatric patient does not comply, oral formulations are difficult to administer, this is the reason why administration routes that can be handled more easily should be proposed by pharmaceutical technologists. Since transdermal drug delivery is cost-effective and easy to use, it can play an important role in producing long-term drug release products, especially in children with chronic diseases. To conclude, scientists from all over the world should work closely to develop safe pediatric formulations for both chronic and acute illnesses.

\section{REFERENCES}

1. van den Anker J, Reed MD, Allegaert K, Kearns GL. Developmental changes in pharmacokinetics and pharmacodynamics. J Clin Pharmacol. 2018;58:S10-25. [CrossRef]

2. Lu H, Rosenbaum S. Developmental pharmacokinetics in pediatric populations. J Pediatr Pharmacol Ther. 2014;19:262-76. [CrossRef]

3. Batchelor HK, Marriott JF. Pediatric pharmacokinetics: key considerations. Br J Clin Pharmacol. 2015;79:395-404. [CrossRef]

4. Allegaert K, van den Anker J. Neonatal drug therapy: The first frontier of therapeutics for children. Clin Pharmacol Ther. 2015;98:288-97. [CrossRef]
5. Rodieux F, Wilbaux $M$, van den Anker JN, Pfister $M$. Effect of kidney function on drug kinetics and dosing in neonates, infants, and children. Clin Pharmacokinet. 2015;54:1183-204. [CrossRef]

6. Mistry P, Batchelor $\mathrm{H}$. Evidence of acceptability of oral pediatric medicines: a review. J Pharm Pharmacol. 2017;69:361-76. [CrossRef]

7. Delgado-Charro MB, Guy RH. Effective use of transdermal drug delivery in children. Adv Drug Deliv Rev. 2014;73:6382. [CrossRef]

8. Batchelor HK, Marriott JF. Formulations for children: problems and solutions. Br J Clin Pharmacol. 2015;79:40518. [CrossRef]

9. Nunn T, Williams J. Formulation of medicines for children. Br J Clin Pharmacol. 2005;59:674-6. [CrossRef]

10. van Riet-Nales DA, Ferreira JA, Schobben AFAM, de Neef BJ, Egberts TCG, Rademaker CMA. Methods of administering oral formulations and child acceptability. Int J Pharm. 2015;491:261-7. [CrossRef]

11. Ernest TB, Craig J, Nunn A, et al. Preparation of medicines for children - A hierarchy of classification. Int J Pharm. 2012;435:124-30. [CrossRef]

12. Fernandez E, Perez R, Hernandez A, Tejada P, Arteta M, Ramos J. Factors and mechanisms for pharmacokinetic differences between pediatric population and adults. Pharmaceutics. 2011;3:53-72. [CrossRef]

13. Perreault L. Obesity in adults: Etiology and risk factors. UpToDate. Available from: https://www.uptodate.com/ contents/obesity-in-adults-etiology-and-risk-factors

14. Faundez T, Klee P, Hanquinet S, Schwitzgebel V, Burkhard PR, Korff CM. Diabetic striatopathy in childhood: a case report. Pediatrics. 2016;137:e20143761. [CrossRef]

15. Alter SJ, Bennett JS, Koranyi K, Kreppel A, Simon R. Common childhood viral infections. Curr Probl Pediatr Adolesc Health Care. 2015;45:21-53. [CrossRef]

16. Limb CJ, Lustig LR, Klein JO. Acute otitis media in adults. UpToDate. Available from: https://www.uptodate.com/ contents/acute-otitis-media-in-adults

17. Alter SJ, Vidwan NK, Sobande PO, Omoloja A, Bennett JS. Common childhood bacterial infections. Curr Probl Pediatr Adolesc Health Care. 2011;41:256-83. [CrossRef]

18. Pichichero ME. Treatment and prevention of streptococcal pharyngitis in adults and children. UpToDate. Available from: https://www.uptodate.com/contents/treatmentand-prevention-of-streptococcal-pharyngitis-in-adultsand-children

19. Barson WJ. Pneumonia in children: Epidemiology, pathogenesis, and etiology. UpToDate. Available from: https://www.uptodate.com/contents/pneumonia-inchildren-epidemiology-pathogenesis-and-etiology

20. Mirra V, Montella S, Santamaria F. Pediatric severe asthma: a case series report and perspectives on anti-IgE treatment. BMC Pediatr. 2018;18:73. [CrossRef]

21. Epling J. Bacterial conjunctivitis. BMJ Clin Evid. 2012;2012:0704. doi: 22348418.

22. Maymone MBC, Watchmaker JD, Dubiel M, Wirya SA, Shen LY, Vashi NA. Common skin disorders in pediatric skin of color. J Pediatr Heal Care. 2019;33:727-37. [CrossRef]

23. Vivar KL, Kruse L. The impact of pediatric skin disease on self-esteem. Int J Women's Dermatology. 2018;4:27-31. [CrossRef]

24. Silverberg NB. Typical and atypical clinical appearance of atopic dermatitis. Clin Dermatol. 2017;35:354-9. 
[CrossRef]

25. Al Humaid J. Sweetener content and cariogenic potential of pediatric oral medications: A literature. Int J Health Sci (Qassim). 2018;12:75-82. Available from: https://www. ncbi.nlm.nih.gov/pmc/articles/PMC5969777/

26. Allen LV. Dosage form design and development. Clin Ther. 2008;30:2102-11. [CrossRef]

27. Breitkreutz J, Boos J. Paediatric and geriatric drug delivery. Expert Opin Drug Deliv. 2007;4:37-45. [CrossRef]

28. European Medicines Agency (EMA). Guideline on pharmaceutical development of medicines for pediatric use [Internet]. 2012. p. 24. Available from: https://www. ema.europa.eu/en/documents/scientific-guideline/ guideline-pharmaceutical-development-medicinespaediatric-use_en.pdf

29. Mennella JA, Beauchamp GK. Optimizing oral medications for children. Clin Ther. 2008;30:2120-32. [CrossRef]

30. Kristensen HG. WHO guideline development of pediatric medicines: Points to consider in pharmaceutical development. Int J Pharm. 2012;435:134-5. [CrossRef]

31. Yochana S, Yu M, Alvi M, Varenya S, Chatterjee P. Pharmaceutical excipientsand pediatricformulations. Chim Oggi/Chemistry Today. 2012;30:56-61. Available from: https://www.researchgate.net/publication/288599708

32. Strickley RG, Iwata Q, Wu S, Dahl TC. Pediatric drugs a review of commercially available oral formulations. J Pharm Sci. 2008;97:1731-74. [CrossRef]

33. Chandrasekaran P, Kandasamy R. Solid oral flexible formulations for pediatric and geriatric patients: ageappropriate formulation platforms. Indian J Pharm Sci. 2018;80:14-25. [CrossRef]

34. Trofimiuk M, Wasilewska K, Winnicka K. How to modify drug release in paediatric dosage forms? Novel technologies and modern approaches with regard to children's population. Int J Mol Sci. 2019;20:3200. [CrossRef]

35. Klingmann V, Seitz A, Meissner T, Breitkreutz J, Moeltner A, Bosse HM. Acceptability of uncoated mini-tablets in neonates-a randomized controlled trial. J Pediatr. 2015;167:893-896.e2. [CrossRef]

36. Van Riet-Nales DA, Kozarewicz P, Aylward B, et al. Paediatric drug development and formulation design-a european perspective. AAPS PharmSciTech. 2017;18:241-9. [CrossRef]

37. Kadhim ZM, Ali WK. Preparation and evaluation of granisetron chewable pediatric oral jelly. Int J Drug Deliv Technol. 2019;9:347-51. Available from: http:// impactfactor.org/PDF/IJDDT/9/IJDDT,Vol9, Issue3, Article4.pdf [CrossRef]

38. Goes J da S, Freire FD, E Moura TFA de L, Aragão CFS, Raffin FN. Preformulation of a liquid dosage formulation of captopril for pediatric use: Drug-excipient compatibility and stability studies. Brazilian J Pharm Sci. 2019;55:e18015. [CrossRef]

39. Aman R, Meshali M, Abdelghani G. Optimization and formulation of cinnarizine-loaded chitosan microspheres in liquid dosage form for pediatric therapy. Drug Deliv Lett. 2014;4:128-41. [CrossRef]

40. Akre HS, Mundhada DR, Bhaskaran S, Asghar S, Gandhi GS. Dry suspension formulation of taste masked antibiotic drug for pediatric use. J Appl Pharm Sci. 2012;2:166-71. [CrossRef]

41. Padmavathi Y, Madhava Reddy B, Amareswar P. Development of fixed dose combination dispersible tablets containing Stavudine, Lamivudine and Nevirapine for paediatric applications. Int J Pharm Technol. 2011;3:2343-52. Available from: https://www. researchgate.net/publication/285830051

42. Omar SM, Ibrahim F, Ismail A. Formulation and evaluation of cyclodextrin-based nanosponges of griseofulvin as pediatric oral liquid dosage form for enhancing bioavailability and masking bitter taste. Saudi Pharm J. 2020;28:349-61. [CrossRef]

43. Nese C, Palugan L, Cerea M, Pinto JF. Preparation and characterization of a powder manufactured by spray drying milk based formulations for the delivery of theophylline for pediatric use. Int J Pharm. 2020;580:119227. [CrossRef]

44. Gerrard SE, Walsh J, Bowers N, Salunke S, Hershenson S. Innovations in pediatric drug formulations and administration technologies for low resource settings. Pharmaceutics. 2019;11:518. [CrossRef]

45. Alshehri A, Barghouthi R, Albanyan S, et al. A prospective, double-blind, randomized, placebo-controlled trial comparing the efficacy of polyethylene glycol versus polyethylene glycol combined with topical diltiazem for treating anal fissure in children. J Pediatr Surg. 2020;55:2017-21. [CrossRef]

46. Bhuva F, Patel L. Pediatric nasal spray solution: factorial design development and evaluation. J Drug Deliv Ther. 2018;8:355-65. [CrossRef]

47. Dreno C, Gicquel T, Harry M, et al. Formulation and stability study of a pediatric $2 \%$ phenylephrine hydrochloride eye drop solution. Ann Pharm Françaises. 2015;73:31-6. [CrossRef]

48. Findling RL, Dinh S. Transdermal therapy for attentiondeficit hyperactivity disorder with the methylphenidate patch (MTS). CNS Drugs. 2014;28:217-28. [CrossRef]

49. Hebert AA, Rosen T, Albareda López N, Zsolt I, Masramon X. Safety and efficacy profile of ozenoxacin $1 \%$ cream in pediatric patients with impetigo. Int J Women's Dermatology. 2020;6:109-15. [CrossRef]

50. Karlsson M, Elmasry M, Steinvall I, Sjöberg F, Olofsson P, Thorfinn J. Superiority of silver-foam over porcine xenograft dressings for treatment of scalds in children: A prospective randomised controlled trial. Burns. 2019;45:1401-9. [CrossRef] 